\title{
IMPLEMENTASI PERANAN EKOSISTEM PENDIDIKAN DALAM PENGUATAN PENDIDIKAN KARAKTER PESERTA DIDIK
}

\author{
Novrian Satria Perdana
}

Pusat Penelitian Kebijakan Pendidikan dan Kebudayaan Jakarta

\section{Info Artikel}

Sejarah Artikel:

Diterima: 9 Feb 2018

Direvisi : 13 Mar 2018

Dipublikasikan: Jun 2018

\section{Keywords:}

Mischief, Strengthening

Character Education,

Educational Ecosystem.

\section{Abstract}

Lately we often see some misbehavior done by learners. Various forms of delinquency of learners increasingly coloring the present life, making parents, teachers, community leaders and even Government restless. As an alternative solution to the problem, the government set a policy of strengthening character education for all people, including education. Given the importance of strengthening character education, it is very interesting to explore how the implementation of the strengthening of character education in schools, so the authors conduct research that aims to examine what the role of educational ecosystem in implementing the strengthening of character education to learners in school. This research uses qualitative method by conducting interviews and surveys to several sample schools namely elementary and junior high school in Semarang city in 2017. Based on the results of analysis, the results obtained that the implementation of character value values by: 1) principal, in the form: socialize school policy about character education, providing exemplary in implementing the character's values to learners, etc. 2) teachers, in the form of: teachers as centers of school civilization, giving equal opportunity to students, assessing and reporting outcomes fairly and transparently (3) staff / education personnel in the form of: neat, polite, etc. 4) parent / community in the form of: as mediator (building a network) with other institutions or communities in the action of n-value investing character values at school, active participation in school adiwiyata, training in schools by inviting experts, and so on. With the synergy in strengthening character education in schools, it will create a conducive atmosphere in the school environment.

\begin{abstract}
Abstrak
Akhir-akhir ini kita sering melihat beberapa aksi kenakalan yang dilakukan oleh peserta didik. Bermacam-macam bentuk kenakalan peserta didik semakin mewarnai kehidupan saat ini, membuat orang tua, guru, tokoh masyarakat dan bahkan Pemerintah resah. Sebagai salah satu alternatif solusi permasalahan, pemerintah menetapkan kebijakan penguatan pendidikan karakter bagi seluruh masyarakat, termasuk bidang pendidikan. Mengingat pentingnya penguatan pendidikan karakter, sangat menarik untuk mendalami bagaimana implementasi penguatan pendidikan karakter di sekolah, sehingga penulis melakukan penelitian yang bertujuan untuk mengkaji apa saja peran ekosistem pendidikan dalam mengimplementasikan penguatan pendidikan karakter kepada peserta didik di sekolah. Penelitian ini menggunakan metode kualitatif dengan melakukan wawancara dan survey ke beberapa sekolah sampel yaitu jenjang SD dan SMP di kota Semarang tahun 2017. Berdasarkan hasil analisis, diperoleh hasil bahwa implementasi nilai-nilai karakter oleh: 1) kepala sekolah, dalam dalam bentuk: mensosialisasikan kebijakan sekolah tentang pendidikan karakter,memberikan keteladanan dalam mengimplementasikan nilai-nilai karakter kepada peserta didik, dan sebagainya, 2) guru, dalam bentuk: guru sebagai pusat peradaban sekolah, memberi kesempatan berpendapat secara merata kepada siswa, menilai dan melaporkan hasil belajar secara adil dan transparan khususnya yang berhubungan dengan penanaman nilai-nilai karakter, membentuk pribadi peserta didik, dan sebagainya, 3) staf/tenaga kependidikan dalam bentuk: berpenampilan rapi, berkata sopan, dan sebagainya, dan 4) orangtua/masyarakat dalam bentuk: sebagai mediator (membangun jejaring) dengan lembaga atau komunitas lain dalam aksi penanaman nilai-nilai karakter di sekolah, berpartisipasi aktif dalam adiwiyata sekolah, mengadakan pelatihan di sekolah dengan mengundang para ahli, dan sebagainya. Dengan adanya sinergitas dalam penguatan pendidikan karakter di sekolah, maka secara langsung akan tercipta suasana kondusif di lingkungan sekolah.
\end{abstract}

(C) 2018 Universitas Muria Kudus 


\section{PENDAHULUAN}

Akhir-akhir ini sedang marak kasus kenakalan anak. Kasus saja terjadi pada bulan Februari 2018 adalah berupa tewasnya seorang guru honorer di Kabupaten Sampang oleh siswanya sendiri saat jam pelajaran berlangsung. Ahmad Budi Cahyono, guru honorer di SMAN 1 Torjun, Kabupaten Sampang, Madura, Jawa Timur, meninggal dunia pasca-mengalami tindak kekerasan yang diduga dilakukan oleh siswanya sendiri. Pemukulan terjadi di ruang kelas IX saat materi seni lukis berlangsung pada jam terakhir pelajaran. Kasus lainnya terjadi di Banjarnegara telah beredar video seorang murid berani menantang kelahi gurunya sendiri. Bahkan siswa tersebut menantang kepala sekolahnya, Ia menantang sambil membuka kancing dan bajunya.

Selain kasus-kasus tersebut, masih banyak pula kasus tawuran pelajar yang dihimpun dari berbagai sumber media online, adanya bentrok antar pelajar yang terjadi pada 9 September 2017 hingga terjadi penganiayaan dan penusukan terhadap dua siswa SMA Negeri di Lombok Timur. Tawuran pelajar juga terjadi di Banten pada 28 September 2017. Pemicu tawuran belasan pelajar adalah dendam lama antarpelajar di dua sekolah yang berbeda, akan tetapi pada saat tawuran pelajar tersebut pelaku juga melibatkan kawan dari sekolah lain. Akibat tawuran itu, satu pelajar mengalami luka bacok di bagian kaki sebelah kiri dan kepala. Kasus tawuran pelajar berikutnya terjadi di Cakung, Jakarta Timur pada 12 Oktober 2017 yang mengakibatkan satu siswa SMK Swasta tewas. Kasus serupa juga terjadi di Kota Bogor yangmana pada tanggal 2 Januari 2018 telah terjadi aksi tawuran puluhan pelajar hingga menewaskan seorang siswa SMK swasta di Kota Bogor.

Kasus kenakalan yang dilakukan oleh peserta didik telah terjadi cukup lama dengan berbagai macam bentuknya.Menurut data yang dirilis oleh KPAI (2016), ada banyak kasus bentuk kenakalan remaja yang kini terjadi, seperti tertuang pada tabel di bawah ini:

Tabel Data Kasus Kenakalan

\begin{tabular}{|c|c|c|c|c|}
\hline Bentuk Kasus & 2014 & 2015 & 2016 & Jumlah \\
\hline $\begin{array}{lll}\begin{array}{l}\text { Anak } \\
\text { pelajar }\end{array} & \text { pelaku tawuran } \\
\end{array}$ & 46 & 126 & 41 & 213 \\
\hline $\begin{array}{l}\text { Anak yang menggunakan } \\
\text { napza (narkotika, minuman } \\
\text { keras, rokok) }\end{array}$ & 63 & 74 & 64 & 201 \\
\hline $\begin{array}{l}\text { Anak sebagai } \text { pengedar } \\
\text { napza (narkotika, }\end{array}$ & 48 & 31 & 17 & 96 \\
\hline
\end{tabular}

\begin{tabular}{|l|l|l|l|l|}
\hline \multicolumn{1}{|c|}{ Bentuk Kasus } & $\mathbf{2 0 1 4}$ & $\mathbf{2 0 1 5}$ & $\mathbf{2 0 1 6}$ & Jumlah \\
\hline $\begin{array}{l}\text { keras, rokok) } \\
\text { kekerasan di sekolah } \\
\text { (bulliying) }\end{array}$ & 67 & 93 & 93 & $\mathbf{2 5 3}$ \\
\hline $\begin{array}{l}\text { Anak sebagai pelaku tindak } \\
\text { kejahatan melalui seksual } \\
\text { online }\end{array}$ & 42 & 52 & 51 & $\mathbf{1 4 5}$ \\
\hline $\begin{array}{l}\text { Anak berhadapan hukum } \\
\text { pelaku kekerasan seksual } \\
\text { (pencabulan, pemerkosaan, } \\
\text { sodomi/pedofilia, dsb) }\end{array}$ & 561 & 157 & 86 & $\mathbf{8 0 4}$ \\
\hline $\begin{array}{l}\text { Anak berhadapan hukum } \\
\text { sebagai pelaku tindakan } \\
\text { pembunuhan }\end{array}$ & 66 & 36 & 31 & $\mathbf{1 3 3}$ \\
\hline $\begin{array}{l}\text { Anak berhadapan hukum } \\
\text { sebagai pelaku tindakan } \\
\text { pencurian }\end{array}$ & 47 & 81 & 24 & $\mathbf{1 5 2}$ \\
\hline $\begin{array}{l}\text { Sumber: Bank Data KPAI } \\
\text { (n) }\end{array}$ & & & & \\
\hline
\end{tabular}

Sumber: Bank Data KPAI 2016

Berdasarkan data pada tabel di atas, jumlah kasus terbesar adalah kasus anak sebagai pelaku kekerasan seksual sebanyak 804 kasus. Banyaknya kasus tersebut dipengaruhi faktor merebaknya konten pornografi maupun porno aksi di era kemajuan global ini. Akses internet yang menyeruak masuk, tidak dibekali dengan pertahanan moral yang cukup pada anak-anak. Hal tersebut mengindikasikan masih lemahnya pengawasan orangtua dalam mengawasi tumbuhkembang karakter anaknya. Kasus lainnya yang sangat memprihatinkan adalah banyaknya anak sebagai pelaku kekerasan di sekolah/ bullying (253 kasus) dan anak pelaku tawuran pelajar (213 kasus). Banyaknya keterlibatan anak-anak dalam kedua kasus tersebut mengindikasikan bahwa sekolah belum ramah anak atau dapat dikatakan adanya kegagalan penanaman pendidikan karakter bagi siswa.

Maraknya kasus kenakalan yang terjadi di masyarakat diduga kurangnya keteladanan (perilaku baik) dan pengawasan intensif dari ekosistem pendidikan termasuk di dalamnya orangtua/masyarakat sehingga menjadi salah satu penyebab tindak kekerasan yang bertentangan dengan nilai-nilai karakter. Peningkatan kasus kenakalan merupakan wujud proses pendewasaan remaja yang tidak tepat. Dalam proses kehidupan menuju pedewasaan, para remaja/peserta didik selalu membutuhkan penyesuaian sosial. Penyesuaian sosial tersebut adalah merupakan suatu kemampuan untuk dapat bereaksi secara cepat, tepat, sehat dan memuaskan terhadap realitas sosial budaya dan situasi lingkungan sosial budaya dengan cara mengubah kebiasaan yang ada dengan 
sedemikian rupa sehingga tuntutan bermasyarakat dapat diterima secara harmonis, dan diterima dengan baik. Seorang peserta didik usia remaja dituntut harus dapat melakukan suatu penyesuaian sosial agar tidak berdampak negatif dalam sosial budaya dalam bermasyarakat. Penyesuaian sosial pada peserta didik merupakan kemampuan peserta didik dalam menjalankan tugas-tugas perkembangan pembelajaran dalam menyesuaikan lingkungan sosialnya seperti di rumah dan keluarga, sekolah dan masyarakat dengan menyeleksi segala sesuatu fenomena yang berasal dari lingkungan yang sesuai dengan kebutuhan dirinya dan sosial sehingga menghantarkannya pada suatu kondisi penyesuaian yang baik dan harmonis untuk perkembangan kepribadian peserta didik tersebut yang sehat.

Kegagalan anak-anak dalam melakukan penyesuaian sosialnya dapat berdampak pada kenakalan. Santrock dalam Puslitjakdikbud (2015) mengatakan hal ini dapat terjadi karena anak-anak lebih banyak menghabiskan waktu dengan teman sebayanya. Anak-anak lebih banyak berada di luar rumah bersama dengan teman-teman sebaya sebagai kelompok daripada di dalam rumah bersama dengan keluarganya. Hal ini dapat disimpulkan bahwa pengaruh teman-teman sebaya terhadap anak-anak pada perubahan sikap/perilaku, etika, gaya bicara, motivasi, penampilan, dan sebagainya lebih besar daripada pengaruh keluarga.

Masih banyaknya kasus-kasus kenakalan anak/peserta didik mengindikasikan bahwa Negara ini sedang dihadapkan pada masalah krisis multidimensional. Sebagai salah satu alternatif mengatasi krisis multidemensional pemerintah menetapkan kebijakan pendidikan budaya dan karakter bangsa. Pendidikan karakter selalu menjadi landasan Negara dalam mewujudkan visi pembangunan nasional, yaitu untuk mewujudkan masyarakat yang berakhlak mulia, berbudi pekerti luhur, bermoral, beretika, berbudaya, dan beradab berdasarkan falsafah Pancasila dan UUD 1945. Pentingnya pendidikan karakter selain karena sebagai landasan negara dalam mewujudkan visi pembangunan nasional, menurut Azizah (2016) menyampaikan bahwa pendidikan karakter juga dapat bertujuan untuk: (1) mengembangkan potensi peserta didik agar menjadi manusia berhati baik, berpikiran baik, dan berperilaku baik; (2) membangun bangsa yang berkarakter Pancasila; (3) mengembangkan potensi warga negara agar memiliki sikap percaya diri, bangga pada bangsa dan negaranya serta mencintai umat manusia.
Pembangunan bangsa dan pembangunan karakter merupakan persoalan mendasar bagi keberlangsungan sebuah bangsa. Bagi bangsa Indonesia pembangunan karakter ini memiliki panduan yang sudah jelas yaitu berdasarkan Pancasila sebagai falsafah/pandangan hidup bangsa dan dasar negara. Ideologi Pancasila merupakan keseluruhan pandangan, cita-cita, maupun keyakinan dan nilai-nilai bangsa Indonesia secara normatif perlu diwujudkan dalam tata kehidupan berbangsa dan bernegara guna mewujudkan tercapainya suatu keadilan sosial bagi seluruh rakyat Indonesia (Rahman 2017).

Penanaman nilai-nilai karakter kepada peserta didik memerlukan strategi pembelajaran dan keahlian tersendiri. Oleh karena itu sekolah dituntut untuk memahami nilai-nilai karakter yang akan ditanamkan kepada peserta didik. Strategi penanaman nilai-nilai karakter dapat dilakukan melalui pembelajaran, pengembangan diri dan pembudayaan sekolah. Pendidikan karakter pada dasarnya merupakan upaya dalam suatu proses menginternalisasikan, menghadirkan, dan mengembangkan nilai-nilai kebaikan pada diri peserta didik. Dengan adanya upaya internalisasi nilai-nilai kebajikan yang ada pada diri peserta didik, diharapkan dapat mewujudkan perilaku baik bagi peserta didik tersebut.

Dalam upaya pembentukan karakter bagi peserta didik, saat ini telah diperkuat dengan adanya Peraturan Presiden No. 87 Tahun 2017 tentang Penguatan Pendidikan Karakter. Dalam Peraturan Presiden tersebut, telah disebutkan bahwa Penguatan Pendidikan Karakter (PPK) adalah suatu gerakan pendidikan di bawah tanggung jawab satuan pendidikan untuk memperkuat karakter peserta didik melalui harmonisasi olah hati, olah rasa, olah pikir, dan olah raga dengan pelibatan dan kerja sama antar satuan pendidikan, keluarga, dan masyarakat sebagai bagian dari Gerakan Nasional Revolusi Mental (GNRM). Melalui Keppres tersebut telah dijelaskan bahwa Gerakan Penguatan Pendidikan karakter dilangsungkan pada setiap jenjang pendidikan. Pelaksanaan gerakan penguatan pendidikan karakter (PPK) pada tiap jenjang melibatkan dan memanfaatkan ekosistem pendidikan yang ada di lingkungan sekolah.

Lickona dalam Suhardi (2018) menyatakan bahwa pendidikan karakter adalah upaya sungguh-sungguh secara sengaja untuk membantu orang untuk memahami, lebih peduli, dan bertindak berdasarkan dengan nilai-nilai etika inti. Pembangunan karakter merupakan 
salah satu upaya perwujudan amanat Pancasila dan Pembukaan UUD 1945 yang dilatarbelakangi oleh realita permasalahan kebangsaan yang berkembang saat ini, seperti: disorientasi dan belum dihayatinya nilai-nilai Pancasila secara menyeluruh, memudarnya kesadaran terhadap nilai-nilai budaya bangsa, ancaman disintegrasi bangsa, melemahnya kemandirian bangsa, dan sebagainya. Mengingat pentingnya pendidikan karakter, Kosim (2011) berpendapat penguatan pendidikan karakter harus diajarkan secara sistematis dan holistik sejak dini dengan menggunakan metode knowing the good, loving the good, dan acting the good. Knowing the good bersifat pengetahuan atau kognitif, loving the good, yakni bagaimana seseorang merasakan dan mencintai kebajikan yang diajarkan, sehingga tumbuh kesadaran bahwa seseorang mau melakukan kebajikan karena dia cinta dengan perilaku kebajikan itu. Selanjutnya mengenai acting the good, yaitu kebiasaan melakukan kebajikan secara spontan. Jika semua dapat terlaksana maka akan terbentuk pribadi yang secara spontan mampu melakukan kebajikan sesuai nilai-nilai yang diajarkan.

Afandi (2011) menyatakan penguatan pendidikan karakter saat ini memiliki peranan yang sangat strategis bagi keberlangsungan dan keunggulan bangsa di masa mendatang. Dalam proses penguatan pendidikan karakter tersebut harus dilakukan dengan melalui perencanaan pembelajaran yang efektif dan efisien, pendekatan pembelajaran yang sesuai, dan metode belajar dan pembelajaran yang efektif. Sesuai dengan sifat nilai pendidikan karakter merupakan usaha bersama sekolah dan oleh karenanya harus dilakukan secara bersama oleh semua guru, semua mata pelajaran, dan menjadi bagian yang tak terpisahkan dari budaya sekolah. Adapun beberapa tujuan pendidikan karakter (1) dapat untuk mengembangkan potensi dasar nurani/afektif peserta didik sebagai manusia dan warga negara agar berhati baik, berpikiran baik, dan berperilaku baik; (2) memperkuat dan membangun perilaku bangsa yang multikultur; (3) menanamkan jiwa kepemimpinan dan tanggung jawab peserta didik sebagai generasi penerus bangsa, (4) mengembangkan kemampuan peserta didik menjadi manusia yang mandiri, kreatif, dan berwawasan kebangsaan, (5) meningkatkan peradaban bangsa yang kompetitif dalam pergaulan dunia.; dan sebagainya. Mengingat pentingnya tujuan pendidikan karakter tersebut, pemerintah
Indonesia telah merumuskan kebijakan dalam rangka pembangunan karakter bangsa.

Dalam Kebijakan Nasional

Pembangunan Karakter Bangsa Tahun 20102025 dalam Marzuki (2012) ditegaskan bahwa karakter merupakan hasil keterpaduan empat bagian, yakni olah hati, olah pikir, olah raga, serta olah rasa dan karsa. Olah hati terkait dengan perasaan sikap dan keyakinan/keimanan, olah pikir berkenaan dengan proses nalar guna mencari dan menggunakan pengetahuan secara kritis, kreatif, dan inovatif, olah raga terkait dengan proses persepsi, kesiapan, peniruan, manipulasi, dan penciptaan aktivitas baru disertai sportivitas, serta olah rasa dan karsa berhubungan dengan kemauan dan kreativitas yang tecermin dalam kepedulian, pencitraan, dan penciptaan kebaruan.

Pemerintah juga telah mengembangkan nilai-nilai utama yang disarikan dari butir-butir standar kompetensi lulusan (Permendiknas No. 23 Tahun 2006) dan dari nilai-nilai utama yang dikembangkan oleh Pusat Kurikulum Kemdikbud. Dari kedua sumber tersebut, seperti yang disampaikan oleh Direktorat PSMP Kemdiknas (2010) menyampaikan nilai-nilai utama yang harus dicapai dalam pembelajaran di sekolah (institusi pendidikan) di antaranya 1) kereligiusan, 2) nasionalisme, 3) kejujuran, 4) kemandirian,5) kecerdasan, 6) percaya diri, 7) ketangguhan, 8) kesantunan, 9) kedisiplinan, 10) kedemokratisan, dan sebagainya. Melengkapi nilai-nilai utama dalam upaya penguatan pendidikan karakter, menurut the Six Pillars of Character, yang dikeluarkan oleh Character Counts Coalition: A Project of the Joseph Institute of Ethics dalam Kamaruddin (2014), perlu dikembangkan enam jenis karakter antara lain: (1) trustworthiness, merupakan salah satu bentuk karakter yang membuat seseorang menjadi memiliki integritas, memiliki nilai kejujuran, dan memiliki nilai loyalitas; (2) fairness, merupakan salah satu bentuk karakter yang membuat seseorang lebih memiliki pemikiran yang lebih terbuka serta tidak suka memanfaatkan orang lain; (3) caring, merupakan salah satu bentuk karakter yang membuat seseorang lebih memiliki sikap kepedulian dan perhatian, baik terhadap orang lain maupun terhadap kondisi sosial di lingkungan sekitarnya; (4) respect, merupakan salah satu bentuk karakter yang membuat seseorang selalu menghargai dan menghormati orang lain; (5) citizenship, merupakan salah satubentuk karakter yang membuat seseorang sadar hukum dan peraturan serta lebih peduli terhadap kondisi lingkungan alam; dan (6) 
Responsibility, merupakan salah satubentuk karakter yang membuat seseorang lebih memiliki rasa tanggung jawab, disiplin, dan selalu melakukan segala sesuatu dengan sebaikbaiknya.

Halstead dan Taylor dalam Samsuri (2012) berpendapat model pembelajaran karakter yang diterapkan antara lain dengan problem solving, cooperative learning, dan experience-based projects yang dapat diintegrasikan ke dalam model pembelajaran tematik dan diskusi untuk menempatkan nilainilai kebajikan ke dalam praktik kehidupan sehari-hari sebagai sebuah pengajaran yang bersifat formal di sekolah. Pengintegrasian nilainilai kebajikan di sekolah perlu dituangkan pada materi pelajaran yang berkaitan dengan norma atau nilai-nilai pada setiap mata pelajaran perlu dikembangkan, dieksplisitkan, dan dikaitkan dengan konteks kehidupan sehari-hari. Dengan demikian, pembelajaran nilai-nilai karakter di sekolah tidak hanya pada tataran kognitif, tetapi menyentuh pada internalisasi dan pengalaman nyata dalam kehidupan sehari-hari di masyarakat. Pendidikan karakter sangat penting untuk diajarkan kepada semua orang, dan salah satu institusi yang dianggap paling efektif dalam mengajarkan pendidikan karakter adalah sekolah. Karyono (2015) mengatakan sekolah menjadi basis pengembangan karakter pada jenjang pendidikan formal. Sekolah merupakan lembaga akademik dengan tugas utamanya adalah untuk menyelenggarakan pendidikan dan mengembangkan ilmu, pengetahuan, teknologi, dan seni. Oleh karena itu, sangat diperlukan model pendidikan karakter yang efektif; sedangkan di sekolah pula, guru mempunyai peranan yang sangat strategis sebagai figur yang langsung berhadapan dengan peserta didik.

Tujuan pendidikan tidak hanya untuk mengembangkan keilmuan, tetapi juga untuk membentuk kepribadian, kemandirian, keterampilan sosial, dan karakter peserta didik. Oleh sebab itu, berbagai program dirancang dan diimplementasikan untuk mewujudkan tujuan pendidikan tersebut, terutama dalam rangka pembentukan karakter. Widodo (2017) menyatakan pembentukan karakter melalui penguatan pendidikan karakter sangatlah penting karena memiliki hakikat bahwa pendidikan yang bertujuan untuk membentuk sebuah generasi yang bijaksana dan memiliki intelektualitas yang didasarkan pada nilai-nilai moral yang baik dan nilai-nilai ketuhanan agar seorang individu tersebut dapat berperilaku arif dan bijaksana bagi dirinya sendiri maupun di dalam masyarakat.
Pendidikan karakter seharusnya dapat dilaksanakan dengan suatu perencanaan oleh sekolah, keluarga, maupun masyarakat. Wahyuningtyas dkk (2017) berpendapat pendidikan karakter merupakan suatu upaya yang disengaja untuk membantu siswa agar memahami, peduli, dan bertindak berdasarkan nilai-nilai inti. Oleh karena itu hal ini dapat diupayakan melalui pemberian ilmu pengetahuan dan penanaman nilai-nilai karakter yang baik pada peserta didik melalui contoh teladan agar peserta didik memiliki karakter berhubungan dengan Tuhan, diri sendiri, sesama sosial dan lingkungan. Telah banyak upaya yang dilakukan oleh sekolah dalam upaya penguatan pendidikan karakter peserta didikantara lain dengan cara mengintegrasikan ke dalam kurikulum, ekstrakulikuler maupun pembiasaan pembiasaan baik di sekolah, pengintegrasian pendidikan karakter di dalam kelas guru mengupayakan metode yang relevan sehingga akan tercipta belajar yang aktif, kreatif dan menyenangkan sehingga berpengaruh pada prestasi belajar siswa.Pendidikan karakter di sekolah tidak akan lepas dari peran kepala sekolah, guru, pendidik dan tenaga kependidikan serta orangtua/masyarakat yang dilibatkan untuk menentukan fokus atau tema nilai-nilai karakter yang ingin dikembangkan di sekolah. Penerapan pendidikan karakter terlebih dahulu mensosialisasikan nilai-nilai tersebut ke seluruh komponen/stake holder sekolah. Nilainilai karakter ditumbuhkan dengan memasukan pada Program kegiatan yang ada di sekolah. Implementasi nilai-nilai karakter dapat dilakukan melalui : (i) pembelajaran di kelas yaitu pada semua mata pelajaran, (ii) pendidikan ekstra kurikuler, (iii) melalui budaya sekolah, dan (iv) kegiatan pembiasaan dalam keseharian di rumah.

Sehubungan dengan uraian yang telah disajikan, dirasa perlu dilakukan suatu pengkajian tentang implementasi peranan ekosistem pendidikan dalam penguatan pendidikan karakter kepada peserta didik. Adapun tujuan dari penelitian ini adalah untuk mengkaji apa saja peran ekosistem pendidikan (kepala sekolah, guru, tenaga kependidikan dan orangtua/masyarakat) dalam penguatan pendidikan karakter kepada peserta didik.

\section{METODE PENELITIAN}

Penelitian penguatan pendidikan karakter di satuan pendidikan menggunakan pendekatan sekolah secara menyeluruh yang mencakup (1) kepemimpinan, pengelolaan dan perubahan pengelolaan, (2) pengembangan kebijakan yang 
ada, (3) perencanaan kurikulum dan sumberdaya, (4) pembelajaran dan pengajaran, (5) budaya dan lingkungan sekolah,(6) pemberian hak mengemukakan pendapat bagi anak-anak dan remaja, (7) penyediaan layanan dukungan untuk anak-anak dan remaja, (8) kebutuhan pengembangan, kesehatan, dan kesejahteraan profesional, (9) kemitraan dengan orang tua / wali dan masyarakat lokal, (10) menilai, mencatat dan melaporkan prestasi anak-anak dan sebagainya.Secara garis besar pendekatan beserta aspek-aspeknya dapat digunakan namun disesuaikan dengan kondisi dan kebutuhan penelitian. Selain itu penelitian juga menggunakan pendekatan inductive reasoning dalam menganalisis data yang sudah diperoleh dalam pengumpulan data.

Pengumpulan data dengan menggunakan instrumen yang telah diujicobakan. Data lapangan dikumpulkan di provinsi/ lokasi yang diharapkan dapat mewakili gambaran tentang kondisi dan permasalahan pendidikan karakter di Indonesia. Sampel penelitian ini adalah 2 SD Negeri, 2 SD Swasta, 2 SMP Negeri dan 2 SMP Swasta di kota Semarang tahun 2017. Pengumpulan data dilaksanakan melalui Focus Group Discussion (FGD) dengan mengundang narasumber daerah yang berasal dari tokoh masyarakat, dinas pendidikan, perguruan tinggi, lembaga, maupun dari sekolah dan survey ke sekolah sampel.

Data yang sudah dikumpulkan kemudian diolah dan dianalisis. Pengolahan dan analisis data pada penelitian kualitatif dilakukan melalui tahapan mengkategorisasikan data, mereduksi data, menyajikan data, dan menarik kesimpulan. Mereduksi data berarti merangkum, memilih hal-hal yang pokok, memfokuskan pada hal-hal yang penting, mencari pola dan informasi yang diperoleh dan membuang informasi yang tidak perlu. Melalui penyajian data, maka data terorganisasikan, tersusun dalam pola hubungan sehingga mudah dipahami. Adapun proses penarikan kesimpulan dan verifkasi dilakukan untuk menemukan bukti-bukti yang kuat sampai diperoleh simpulan yang kredibel.

\section{HASIL DAN PEMBAHASAN}

Peranan kepala sekolah terkait dengan penanaman nilai-nilai karakter pada sekolahsekolah yang menjadi sasaran antara lain: pertama, dalam hal mensosialisasikan kebijakan sekolah tentang pendidikan karakter. Adapun peran kepala sekolah dalam hal mensosialisasikan kebijakan sekolah tentang pendidikan karakter dapat diklasifikasikan sebagai berikut: mengadakan sosialisasi kepada guru mengenai pendidikan karakter melalui rapat rutin dan pada saat upacara bendera, mengadakan pelatihan, mendelegasikan pelaksanaan pendikar kepada guru dan staf, melaksanakan bimbingan kepada guru, mengadakan lomba-lomba, memberikan keteladanan dan motivasi kepada guru, membuat tata tertib, dan menjalin kerjasama dengan orang tua untuk memberikan keteladanan kepada anak-anaknya di rumah. Kedua, dalam hal kebijakan penanaman nilainilai karakter di sekolah.

Adapun peran kepala sekolah dalam hal kebijakan penanaman nilai-nilai karakter di sekolah dapat diklasifikasikan sebagai berikut: melaksanakan pembiasaan rutin, memberikan keteladanan kepada seluruh warga sekolah, menuangkan nilai-nilai karakter dalam visi dan misi sekolah, menganggarkan pelaksanaan pendidikan karakter dalam RKAS, melakukan sosialisasi kepada guru, orang tua, dan siswa, melaksanakan bimbingan kepada guru dan siswa, dan menugaskan guru membuat RPP berkarakter. Ketiga, dalam hal pengelolaan penyelenggaraan nilai-nilai karakter di sekolah.

Peran kepala sekolah dalam hal pengelolaan penyelenggaraan nilai-nilai karakter di sekolah dapat diklasifikasikan sebagai berikut: melaksanakan pembiasaan rutin, memberikan keteladanan kepada seluruh warga sekolah, melakukan sosialisasi kepada guru, orang tua, dan siswa, melakukan pengawasan, membuat tata tertib dan memberikan sanksi apabila ada yang melanggar, menyelenggarakan kegiatan ekstrakurikuler, dan melaksanakan kerjasama dengan pihak terkait. Keempat, dalam hal pembinaan (pengembangan profesi) PTK di sekolah.

Mengenai peran kepala sekolah dalam hal pembinaan (pengembangan profesi) PTK di sekolah dapat diklasifikasikan sebagai berikut: mengadakan pelatihan di sekolah dengan mengundang para ahli, menugaskan guru untuk pelatihan di luar sekolah, menyelenggarakan MGMP, menyusun RPP berkarakter, dan melaksanakan bimbingan kepada guru secara berkala, dan memberikan motivasi kepada guru untuk melaksanakan pendidikan karakter di sekolah. Kelima, dalam hal pemberian layanan khusus kepada peserta didik yang membutuhkan.

Adapun peran kepala sekolah dalam hal pemberian layanan khusus kepada peserta didik yang membutuhkan dapat diklasifikasikan sebagai berikut: membuka kelas akselarasi dan CIBI, membangun komunikasi dengan orang tua, menyediakan fasilitas buku dan sarana 
penunjang K13, mendelegasikan kepada guru BK dan rohani, melaksanakan bimbingan kepada siswa, dan menyelenggarakan remedial. Keenam, dalam hal keteladanan dalam mengimplementasikan nilai-nilai karakter. Adapun peran kepala sekolah dalam hal keteladanan dalam mengimplementasikan nilainilai karakter dapat diklasifikasikan sebagai berikut: memberikan keteladanan dalam mengimplementasikan nilai-nilai karakter dan melaksanakan pembiasaan rutin sekolah.

Peranan guru dalam penanaman nilainilai karakter pada sekolah-sekolah yakni pertama, dalam hal mensosialisasikan kebijakan sekolah tentang pendidikan karakter. Adapun peran guru dalam hal mensosialisasikan kebijakan sekolah tentang pendidikan karakter dapat diklasifikasikan sebagai berikut: melaksanakan pembiasaan rutin, membuat program dan menanaman/menyisipkan nilai karakter pada siswa pada saat proses pembelajaran, melaksanakan sosialisasi tata tertib kepada siswa, melaksanakan bimbingan, dan memberikan contoh keteladanan.

Kedua, dalam hal keteladanan pada implementasi nilai-nilai karakter. Adapun peran guru dalam hal keteladanan pada implementasi nilai-nilai karakter adalah memberi contoh keteladanan dan melaksanakan pembiasaan rutin di sekolah.

Ketiga, dalam hal memberikan kesempatan berpendapat secara merata kepada siswa. Adapun peran guru dalam hal memberi kesempatan berpendapat secara merata kepada siswa dapat diklasifikasikan sebagai berikut: membiasakan siswa untuk berpendapat/bertanya pada saat pembelajaran, guru menjadi fasilitator dan motivator dalam pembelajaran, menampung aspirasi siswa, memberikan keteladanan, mengadakan rapat OSIS, menerapkan metode pembelajaran belajar kelompok, dan memberikan tugas presentasi baik mandiri dan kelompok. Keempat, dalam hal memberikanpenilaian dan melaporkan hasil belajar khususnya yang berhubungan dengan penanaman nilai-nilai karakter.

Adapun peran guru dalam hal menilai dan melaporkan hasil belajar khususnya yang berhubungan dengan penanaman nilai-nilai karakter dapat diklasifikasikan sebagai berikut: membuat alat dan format penilaian sikap (LHPKPD) untuk menilai hasil penanaman nilai siswa dalam bentuk observasi, portofolio, dan rubric, melaksanakan penilaian sikap yang terintegrasi dengan pelaksanaan ulangan, tugas kelompok dan mandiri, dan melaporkan hasil penilaian secara berkala kepada orang tua dan guru BK.

Kelima, dalam memberikan layanan khusus bagi peserta didik yang membutuhkan. Adapun peran guru dalam hal memberikan layanan khusus bagi peserta didik yang membutuhkan dapat diklasifikasikan sebagai berikut: membangun komunikasi dengan orang tua siswa, menyediakan fasilitas yang diperlukan, menyediakan waktu untuk bimbingan, berkoordinasi dengan guru BK dan guru lainnya, dan memberikan pelajaran tambahan dan remedial. Selanjutnya peranan staf/tenaga kependidikan dalam mendukung penyelenggaraan pendidikan karakter pada sekolah-sekolah antara lain: pertama, dalam hal pengusulan sarana pendukung serta aktivitas di sekolah dengan kegiatan yang berhubungan dengan pendidikan karakter. Adapun peran staf di sekolah/tenaga kependidikan dalam pengusulan sarana pendukung serta aktivitas di sekolah dengan kegiatan yang berhubungan dengan pendidikan karakter dapat diklasifikasikan sebagai berikut: menyediakan sarana ekstrakurikuler yang memadai, mengajukan usulan mengenai apa yang dibutuhkan dalam pelaksanaan pendidikan karakter, menyediakan sarana kebersihan, memberikan pelayanan kepada guru, menciptakan suasana sekolah yang kondusif, mengadakan kerjasama dengan guru dan warga sekolah, menyusun format penilaian hasil penanaman nilai, memberikan keteladanan, membantu adminstrasi guru, dan memasang CCTV. Kedua, dalam hal menjadi teladan dalam mengimplementasikan nilai-nilai pendidikan karakter. Adapun peranan tersebut adalah memberikan contoh keteladanan kepada siswa di sekolah seperti membuang sampah pada tempatnya, berpenampilan rapi, berkata sopan, dan sebagainya. Terakhir adalah adalah peranan orangtua terhadap penyelenggaraan pendidikan karakter diuraikan sebagai berikut: pertama, dalam hal memberikan dukungan program sekolah yang berhubungan dengan pendidikan karakter.

Adapun peran orang tua/masyarakat dalam memberi dukungan program sekolah yang berhubungan dengan pendidikan karakter dapat diklasifikasikan sebagai berikut: membantu kegiatan sekolah, mengadakan berkoordinasi dengan guru BK, memberikan keteladanan, mengadakan kerjasama dengan sekolah, memeriksa tugas yang diberikan guru kepada anaknya, mendukung pelaksanaan tata tertib di sekolah, dan melaksanakan pengawasan terhadap anaknya di rumah. Kedua, sebagai 
teladan dalam implementasi nilai-nilai karakter. Adapun peran orang tua/masyarakat sebagai teladan dalam implementasi nilai-nilai karakter dapat diklasifikasikan sebagai berikut: memberikan keteladanan kepada anak-anaknya di rumah/keluarga, mendukung pelaksanaan pendikar di sekolah, melaksanakan pembiasaan rutin di keluarga, dan memberikan motivasi kepada anak-anaknya untuk berperilaku terpuji. Ketiga, sebagai mediator (membangun jejaring) dengan lembaga atau komunitas lain dalam aksi penanaman nilai-nilai karakter di sekolah. Adapun peran orang tua/masyarakat sebagai mediator (membangun jejaring) dengan lembaga atau komunitas lain dalam aksi penanaman nilai-nilai karakter di sekolah dapat diklasifikasikan sebagai berikut: memberikan sumbangan pohon, mengadakan bank sampah, melaksanakan pertukaran siswa dalam bentuk sister parent, mengadakan kerjasama dengan masyarakat dan instansi terkait, membentuk komite sekolah, website dan kotak pengaduan, dan menjadi fasilitator dan mediator kegiatan sekolah. Keempat, sebagai nara sumber dalam aksi penanaman nilai-nilai karakter di sekolah. Adapun peran orang tua/masyarakat dalam hal aksi penanaman nilai-nilai karakter di sekolah dapat diklasifikasikan sebagai berikut: berpartisipasi dalam adiwiyata sekolah, mengadakan pelatihan di sekolah dengan mengundang para ahli, menghadiri undangan sekolah, mendukung kegiatan sekolah pada awal dan akhir tahun, memberikan informasi mengenai karakteristik anaknya di rumah, dan menjadi sumber informasi bagi orang tua siswa lainnya.

\section{SIMPULAN DAN SARAN}

Program penguatan pendidikan karakter tidak akan berhasil tanpa sinergitas dari ekosistem pendidikan. Ekosistem pendidikan antara lain terdiri dari Kepala Sekolah, Guru, Staf/Tenaga Kependidikan, dan orangtua/masyarakat. Implementasi peranan kepala sekolah dalam melaksanakan penguatan pendidikan karakter di sekolah dalam bentuk: mensosialisasikan kebijakan sekolah tentang pendidikan karakter (guru sebagai pusat peradaban sekolah), kebijakan penanaman nilainilai karakter di sekolah (pembentuk karakter peserta didik), pengelolaan penyelenggaraan nilai-nilai karakter di sekolah, pembinaan (pengembangan profesi) PTK di sekolah, pemberian layanan khusus kepada peserta didik yang membutuhkan, dan memberikan keteladanan dalam mengimplementasikan nilainilai karakter.
Selanjutnya implementasi peranan guru dalam melaksanakan program penguatan pendidikan karakter di sekolah dalam bentuk: mensosialisasikan kebijakan sekolah tentang pendidikan karakter, memberikan keteladanan dalam mengimplementasikan nilai-nilai karakter kepada peserta didik, memberi kesempatan berpendapat secara merata kepada siswa, menilai dan melaporkan hasil belajar secara adil dan transparan khususnya yang berhubungan dengan penanaman nilai-nilai karakter, dan memberikan layanan khusus bagi peserta didik yang membutuhkan.

Bentuk-bentuk implementasi peranan staf/tenaga kependidikan dalam melaksanakan penguatan pendidikan karakter di sekolah dalam misalnya dalam hal pengusulan sarana pendukung serta aktivitas di sekolah dengan kegiatan yang berhubungan dengan pendidikan karakter, dan berpenampilan rapi, berkata sopan, dan sebagainya.

Peranan ekosistem pendidikan yang terakhir adalah dari orangtua/masyarakat dalam hal penguatan pendidikan karakter kepada peserta didik antara lain dalam bentuk memberikan dukungan program sekolah yang berhubungan dengan pendidikan karakter, mendukung pelaksanaan pendikar di sekolah, melaksanakan pembiasaan rutin di keluarga,sebagai mediator (membangun jejaring) dengan lembaga atau komunitas lain dalam aksi penanaman nilai-nilai karakter di sekolah, berpartisipasi aktif dalam adiwiyata sekolah, mengadakan pelatihan di sekolah dengan mengundang para ahli, dan sebagainya.

Sinergitas dalam penguatan pendidikan karakter di sekolah, maka secara langsung akan tercipta suasana kondusif di lingkungan sekolah dan akan berdampak positif pada peningkatan karakter peserta didik. Dalam upaya penguatan pendidikan karakter di sekolah harus terus melibatkan semua komponen (stakeholders) termasuk komponen-komponen pendidikan itu sendiri, yaitu isi kurikulum, proses pembelajaran dan penilaian, penanganan atau pengelolaan mata pelajaran, pengelolaan sekolah, pemberdayaan sarana prasarana, pembiayaan, dan etos kerja seluruh ekosistem pendidikan. Keberhasilan dalam upaya penguatan pendidikan karakter dimulai dengan pemahaman karakter yang baik oleh ekosistem pendidikan, mencintainya, dan melaksanakan atau meneladani karakter tersebut sebagai suatu kebiasaan. Dengan demikian, penguatan pendidikan karakter tidak sekedar diajarkan akan tetapi yang paling terpenting adalah dicontohkan dan diamalkan oleh seluruh elemen 
ekosistem pendidikan dalam mewujudkan tujuan pendidikan karakter.

Berdasarkan simpulan di atas, maka diusulkan beberapa saran yakni 1) pelaksanaan penguatan pendidikan karakter di sekolah dilakukan melalui pengintegrasian nilai-nilai karakter ke dalam seluruh mata pelajaran yang diajarkan, 2) pelaksanaan penguatan pendidikan karakter di sekolahdapat juga dilakukan dengan cara mengintegrasikan nilai-nilai karakter kepada peserta didik saat dilakukan kegiatan pembinaan peserta didik seperti misalnya kegiatan ekstrakurikuler, 3) pelaksanaan penguatan pendidikan karakter di sekolah dapat pula dilaksanakan melalui beberapa kegiatan pengelolaan manajemen sekolah yang melibatkan ekosistem pendidikan, dan 4) Pelaksanaan penguatan pendidikan karakter di sekolah harus berupa gerakan menyeluruh yang dilakukan secara bersama-sama kepada ekosistem pendidikan (kepala sekolah, guru, staf/tendik, peserta didik dan orangtua/masyarakat) dengan membuat sistem reward and punishment sehingga tercipta suatu gerakan pendidikan karakter sebagai suatu pembiasaan.

\section{DAFTAR PUSTAKA}

Afandi, Rifki. 2011. Integrasi Pendidikan Karakter Dalam Pembelajaran IPS di Sekolah Dasar. Jurnal Pedagogia, 1 (1).

Azizah, Aida dkk. 2016. Karakter Tokoh Dalam Novel Langit Mekah Berkabut Merah Karya Geidurrahman Al-Mishry Berbasis Nilai-Nilai Karakter Religius Dan Implikasinya Dalam Pembelajaran Sastra Di Madrasah Aliyah. Jurnal Refleksi Edukatika, 7 (1).

Dit PSMP Kemdiknas. 2010. Buku Pendidikan Karakter Terintegrasi dalam Pembelajaran di Sekolah Menengah Pertama. Jakarta: Direktorat PSMP Kemdiknas.

Kamaruddin, Syamsu A. 2014. Mahasiswa dan Perilaku Berkarakter: Studi Sosiologis terhadap Pendidikan Karakter di Fakultas Keguruan dan Ilmu Pendidikan UVRI Makassar, Sulawesi Selatan. Sosiohumanika: Jurnal Pendidikan Sains Sosial dan Kemanusiaan, 7 (1).
Karyono, Hari. 2015. Implementasi Pendidikan Karakter di Taman Kanak-kanak: Studi Kasus pada Taman Kanak-kanak Kemala Bhayangkari 97 Gasum, Pusdik Porong, Jawa Timur, Indonesia. Sosiohumanika: Jurnal Pendidikan Sains Sosial dan Kemanusiaan, 8 (2).

Komisi Perlindungan Anak Indonesia. 2016. Data Kasus Kenakalan Remaja. Diakses melalui website: www.kpai.go.id pada tanggal 04 Februari 2018

Kosim, Mohammad. 2011. Urgensi Pendidikan Karakter. Jurnal Karsa, IXI (1).

Lestari, Indah. 2014. Pengembangan Media Bimbingan Dan Konseling Berbasis Islami Untuk Membentuk Karakter Mandiri Anak Usia Dini. Jurnal Refleksi Edukatika, 4 (1).

Marzuki. 2012. Pengintegrasian Pendidikan Karakter Dalam Pembelajaran Di Sekolah. Jurnal Pendidikan Karakter, Tahun II (1).

Pusat Penelitian Kebijakan Pendidikan dan Kebudayaan (Puslitjakdikbud). 2015. Buku Laporan Penelitian Isu Aktual: Kajian Tindak Kekerasan Siswa Jenjang Pendidikan Menengah. Balitbang Kemendikbud.

Rahman, Maman, dkk. 2017. Pengembangan Model Manajemen Pelatihan Dan Pengembangan Pendidikan Karakter Berlokus Padepokan Karakter. Jurnal Refleksi Edukatika, 8 (1): 16-26.

Samsuri. 2012. Buku Pendidikan Karakter Warganegara. Surakarta: Pustaka Hanif.

Suhardi. 2018. Nilai-Nilai Pendidikan Karakter Dalam Dongeng Putra Lokan. Jurnal Lingua, XIV (1).

Wahyuningtyas, Agustin dkk. 2017. Manajemen Pendidikan Karakter Pada SMP Full Day School di Kota Yogyakarta. Jurnal Akuntabilitas Manajemen Pendidikan, 5 (1).

Widodo, Suprih. 2017. Pendidikan Karakter Dalam Pembelajaran Matematika di Sekolah Dasar. Jurnal Metodik Didaktik, 12 (2). 